\title{
Supporting Mature Aged Students \\ to Develop Group Work Skills: \\ A Review of a 2-Year Study of Students' Experience of Group Work within their Pre-Nursing Program
}

\author{
Deanna McCall \\ Student Central \\ Bronwyn Relf \\ English Foundation and Studies Centre \\ University of Newcastle, Australia
}

\begin{abstract}
The University of Newcastle offers a tertiary preparation program that enables mature aged students to gain access to higher education. One of the largest intakes is into the pre-nursing program. This paper will share the findings of a 2-year study of tertiary preparation students undertaking group work within their pre-nursing program. For many mature-aged students returning to study, it requires the development and transition of their identity from that of an adult role to that of a student role. The aim of this study was to examine how group work can help support mature aged students in their transition to a student identity. The premise was to enable students to develop skills for success in their undergraduate nursing studies, whilst fostering social connection and a sense of belonging in the university. We identified an essential aspect of nursing as being able to work collaboratively with other nurses and within allied health teams. Keeping this in mind, we developed and delivered an approach that introduced group work in Week 3 of the students' program to enable them to effectively integrate curricula and co-curricular learning experiences. Using an online assessment tool called SPARK, students were each asked to self-reflect upon their individual role and their role within the group according to specific criteria that promoted positive group work behaviours and fostered social connection. It was hoped that by providing students with resources and evaluation tools they would develop group work and self-reflection skills to succeed in their studies and future profession.
\end{abstract}

\section{Keywords}

Group work assessment, Mature aged students, Nursing and Midwifery, Enabling education, The University of Newcastle

\section{Introduction}

Mature aged students returning to study require assistance when transitioning from their adult roles into their new student role (Dawson, 2007), including overcoming academic, social and cultural barriers to success (Klinger \& Murray, 2011). The University of Newcastle's Open Foundation (OF) program provides mature aged students with the opportunity to qualify for entry to tertiary study and is widely known as an enabling program. Many OF students come from a low socioeconomic (SES) background or are first-in-family to attend university. Prior to enrolling in their enabling program their confidence in their ability to learn as a student, and to identify as a student, is low (Relf et al., 2017). Debenham and May (2005) identified academic success in the first assessment helps establish student identity.

The Open Foundation Program is distinct from other enabling courses because it provides the development of academic skills embedded in discipline specific contexts (Relf et al., 2017). The 'Science for Nursing and Midwifery' suite of courses has one of the largest enrolments within the OF program, with over 800 enrolments annually. Students choosing to enrol in these courses hope to gain access to an undergraduate degree in nursing, midwifery or an associated health area. Many of the students entering these courses have not studied for a number of years. As a result, "Science for Nursing and Midwifery' courses focus on preparing students for entry into first year undergraduate nursing. For students aspiring to enter undergraduate nursing, understanding and demonstrating skills 
required for working in groups is necessary for both academic and later professional life (Smith \& Rogers, 2014). Furthermore, students and nurses must develop their ability to be reflective about their skills and knowledge in order to be successful in both their academic and professional lives (Jackson et al., 2014). As such, delivery of effective courses in group skill development is essential.

Group work is one type of assessment method that can be used by university academics to help develop these skills in students and encourage peer learning (Willey, 2014). There is an established body of literature for perceptions and experiences of group work at the undergraduate level but there remains a lack of research in this area of enabling programs.

Research has identified that undergraduate students find group work to be a source of anxiety (Davies, 2009; Smith \& Rogers 2014; Willey, 2014). However, group work provides students with a social context for their studies. Developing a student identity involves an emotional commitment to develop this identity through social contexts, provided early in a student's program of study (Whannell \& Whannell, 2015). In 2015 we presented the results of a pilot study undertaken with one cohort of enabling nursing students (McCall \& Relf, 2015). These results investigated how scaffolded group work can support the transition of these students through their studies, helping to create a sense of belonging within the university and to develop a stronger student identity. In the previous study, group work was the vehicle for introducing students to each other and forming social connections within the group.

Part of the group work assessment was to use an online Self and Peer Assessment Resource Kit (SPARK). Use of SPARK has been shown to engage students in group work and reduce the associated anxiety around it (Willey, 2014). Group work, in combination with SPARK, enables students to develop and improve their learning and judgement. It encourages students to reflect on their contribution, in order to receive feedback that can inform their future learning (Willey, 2014).

Peer learning is also an effective teaching and support strategy to engage first year students in their tertiary studies and is particularly useful for those from low SES backgrounds (Devlin, Kift, Nelson, Smith \& McKay, 2012; Thomas, 2010). Kift, Nelson and Clarke's (2010) First Year Experience (FYE) principles are equally applicable to students entering tertiary enabling programs.

In this paper, we present the findings of a follow-up study and report how curricula and co-curricular learning experiences can help establish student identity for enabling students. The purpose of this follow up study was to evaluate the effectiveness of a teaching strategy that has been designed to support mature aged students' development of academic and non-academic skills through group work. By focussing on Open Foundation students, we hoped to obtain information about teaching strategies supportive of students from non-traditional backgrounds, as they transition to their learning role and student identity in their university studies.

\section{Research design}

This project used a descriptive research design to assess the effectiveness of an innovative group work teaching strategy. This project was approved by The University of Newcastle's Human Research Ethics Committee (approval H-2015-0072).

Previously we designed a teaching strategy that incorporates a group work assessment task, in combination with a pre-assessment group skill building workshop, alongside the Self and Peer Assessment Resource Kit (SPARK; Willey 2014). The focus of this strategy was to support students' experience of success in their first assessment and to help them develop social connections with fellow students (McCall \& Relf, 2105). In Week 3 of the 'Science for Nursing and Midwifery' courses in Open Foundation, students were given their first assessment task: a group work assignment, requiring students to research and deliver a presentation on an allocated medical condition (McCall \& Relf, 2015). At this time, students participated in an in-class pre-assessment skills building workshop designed to develop their group work skills. 
The pre-assessment skills building workshop was developed to support students with co-curricular skills and strategies for their group work assignment, which was an embedded teaching strategy that included the requirement for students to work in groups. The effectiveness of this strategy was assessed using an 'in-class' paper-based survey containing 5-point Likert-scale items and open-ended questions constructed by McCall and Relf (2015). The survey was administered to students twice during the semester. The experiences and perceptions of students who participated in the group work, was captured both prior to and after completion of the group work skills workshop. After undertaking a literature review of relevant research, the survey questions were constructed to elucidate students' experiences and perceptions of group work. The questions in the survey align with the benefits of group work and self and peer assessment, as reported in the literature.

The Pre-Group Work survey (Appendix 1), was administered in Week 3, before the pre-assessment skills building workshop, and captured students' perceptions of the benefits of group work prior to starting. A second survey, the Post-Group Work survey (Appendix 2), was administered in Week 9, after students had completed their group work assignment, and focussed on capturing any changes in their perception of group work.

\section{Participants}

Students enrolled in the part-time 'Science for Nursing and Midwifery' courses were invited to participate in the survey during their first semester at university.

\section{Analysing and reporting}

Responses to the 5-point Likert scale survey questions were analysed using SPSS (version 25). To gain a clear understanding of students' responses to open ended survey questions, a thematic analysis of students' responses was undertaken to generate themes as aligned with Braun and Clarke's (2014) approach.

\section{Findings}

\section{Descriptive statistics}

A total of 172 students answered the Pre-Group Work survey and 124 students completed the PostGroup Work survey (Table 1).

Table 1 presents the number of students in each age bracket who participated in the Pre-Group Work and Post-Group Work surveys. The frequency of responses to survey questions for the Pre-Group Work survey and the Post-Group Work survey questions are presented in Table 2.

The aggregated mean response to Pre-Group Work and Post-Group Work survey questions are presented in Tables 3 and 4.

Table 1: Survey participants by age bracket.

\begin{tabular}{|l|l|l|}
\hline Age & $\begin{array}{l}\text { Pre-Group } \\
\text { Work }(\boldsymbol{n})\end{array}$ & $\begin{array}{l}\text { Post-Group } \\
\text { Work }(\boldsymbol{n})\end{array}$ \\
\hline <20 yrs & 25 & 23 \\
\hline $21-25$ yrs & 76 & 39 \\
\hline $25-30$ yrs & 26 & 18 \\
\hline $31-40$ yrs & 26 & 25 \\
\hline $41-50$ yrs & 17 & 16 \\
\hline$>51$ yrs & 2 & 3 \\
\hline TOTAL & $\mathbf{1 7 2}$ & $\mathbf{1 2 4}$ \\
\hline Missing & 1 & 2 \\
\hline
\end{tabular}


Table 2: Frequency of response for Pre-Group Work and Post-Group Work survey questions

\begin{tabular}{|l|l|l|l|l|l|l|l|l|}
\cline { 2 - 10 } \multicolumn{1}{l|}{} & \multicolumn{3}{l|}{ Pre-Group Work survey } & \multicolumn{3}{l|}{ Post-Group Work survey } \\
\cline { 2 - 10 } & $\begin{array}{l}\text { A/SA* } \\
(\%)\end{array}$ & $\mathrm{U}(\%)$ & $\begin{array}{l}\mathrm{D} / \mathrm{SD} \\
(\%)\end{array}$ & Mean & $\begin{array}{l}\text { A/SA* } \\
(\%)\end{array}$ & $\begin{array}{l}\mathrm{U}(\%) \\
(\%)\end{array}$ & Mean \\
\hline Socially beneficial & 81 & 17 & 2 & 4.01 & 78 & 15 & 8 & 3.91 \\
\hline Helpful to my learning & 86 & 10 & 5 & 4.11 & 69 & 20 & 10 & 3.90 \\
\hline $\begin{array}{l}\text { Improve my self } \\
\text { confidence }\end{array}$ & 72 & 23 & 5 & 3.92 & 65 & 20 & 14 & 3.62 \\
\hline Engage me in learning & 81 & 16 & 3 & 4.09 & 76 & 18 & 6 & 3.90 \\
\hline $\begin{array}{l}\text { Enable me to learn from } \\
\text { thers }\end{array}$ & 91 & 7 & 2 & 4.28 & 77 & 14 & 9 & 3.90 \\
\hline
\end{tabular}

* A/SA = Agree/Strongly Agree; U= uncertain; D/SD = Disagree/Strongly Disagree

\# Some percentages do not add up to $100 \%$ because there were missing responses for some questions.

Table 3: Aggregated mean response by Age for Pre-Group Work survey questions:

\begin{tabular}{|l|l|l|l|l|l|}
\hline Age $(\mathrm{n})$ & $\begin{array}{l}\text { Socially } \\
\text { beneficial }\end{array}$ & $\begin{array}{l}\text { Helpful to my } \\
\text { learning }\end{array}$ & $\begin{array}{l}\text { Improve my } \\
\text { self-confidence }\end{array}$ & $\begin{array}{l}\text { Engage me in } \\
\text { learning }\end{array}$ & $\begin{array}{l}\text { Enable me to } \\
\text { learn from } \\
\text { others }\end{array}$ \\
\hline 20 yrs $(25)$ & 4.08 & 4.04 & 3.92 & 3.96 & 4.40 \\
\hline $21-25$ yrs $(76)$ & 4.03 & 4.01 & 3.88 & 4.09 & 4.22 \\
\hline $26-30$ yrs $(26)$ & 3.88 & 4.04 & 3.76 & 3.96 & 4.31 \\
\hline $31-40$ yrs $(25)$ & 3.92 & 4.19 & 3.85 & 4.04 & 4.23 \\
\hline $41-50$ yrs $(17)$ & 4.06 & 4.53 & 4.35 & 4.53 & 4.35 \\
\hline$>51$ yrs $(2)$ & 4.50 & 4.50 & 4.50 & 4.50 & 4.50 \\
\hline
\end{tabular}

Table 4: Aggregated mean response by Age for Post-Group Work survey questions:

\begin{tabular}{|l|l|l|l|l|l|}
\hline Age $(\mathrm{n})$ & $\begin{array}{l}\text { Socially } \\
\text { beneficial }\end{array}$ & $\begin{array}{l}\text { Helpful to my } \\
\text { learning }\end{array}$ & $\begin{array}{l}\text { Improve my } \\
\text { self-confidence }\end{array}$ & $\begin{array}{l}\text { Engage me in } \\
\text { learning }\end{array}$ & $\begin{array}{l}\text { Enable me to } \\
\text { learn from } \\
\text { others }\end{array}$ \\
\hline 20 yrs (23) & 4.04 & 3.87 & 3.78 & 3.91 & 4.04 \\
\hline $21-25$ yrs (39) & 4.03 & 3.67 & 3.74 & 3.97 & 3.92 \\
\hline $26-30$ yrs (18) & 3.72 & 3.56 & 3.24 & 3.61 & 3.56 \\
\hline $31-40$ yrs (25) & 4.04 & 3.72 & 3.60 & 4.00 & 4.24 \\
\hline $41-50$ yrs $(16)$ & 3.63 & 3.69 & 3.50 & 3.87 & 3.56 \\
\hline$>51$ yrs $(3)$ & 3.33 & 3.33 & 3.67 & 4.00 & 3.33 \\
\hline
\end{tabular}

Overall, the majority of students of all ages agreed or strongly agreed that participating in group work was socially beneficial both prior to and after completing group work (Table 2). However, differences were seen in responses to each of these questions between age groups (Tables $3 \& 4$ ). Prior to commencing group work, students aged 41 years and over were more positive about the anticipated social benefits to be gained from participating in group work than they were after completing the preassessment skills building workshop (Tables $3 \& 4$ ). In the Post-Group Work survey, students in all other age groups answered this question relating to the social benefit of group work with similar ratings as the same question in the Pre-Group Work survey. After completion of the group work assignment, students aged 41 years and over answered less positively, indicating that participating in group work had been somewhat less socially beneficial for them.

Prior to commencing group work, students responded more favourably to the question that explored group work being helpful to their learning than after the completion of the group work (Tables $3 \&$ 4). A breakdown of responses to this question based on age indicated that students over the age of 41 years, after completing group work, rated their responses the least positively across the student age 
groups (Tables $3 \& 4$ ). A similar trend was seen in the responses to questions exploring improving my self-confidence, engaged me in learning and enabled me to learn from others (see Tables 3 \& 4).

Students in the 26-30 years age bracket responded to questions improving my self-confidence, engaged me in learning and enabled me to learn from others less positively after completion of the group work, compared with perceptions of the group work prior to commencing the group work assignment. The responses from students aged 26-30 years were less positive about working in groups than students aged under 25 years and overall more positive than the students aged over 41 years (Table 4.).

\section{Did students find the pre-assessment skills building workshop beneficial?}

Prior to commencing group work, $44 \%$ of students agreed that the pre-assessment skills building workshop provided them with confidence to undertake group work compared to $11 \%$ of students who considered the workshop did not enhance their confidence. After completing group work, $28 \%$ of students considered the pre-assessment skills building workshop provided them with skills to help manage possible challenges while working in groups.

Comments indicated that the pre-assessment skills building workshop provided a fair overview of the challenges associated with group work and gave strategies to help with group expectations and experiences during group work. The students' verbatim statements on the pre-assessment skills building workshop indicated that students felt more prepared to undertake group work: "well, makes me comfortable in begin the assessments knowing everyone has seen the roles and responsibilities" and "I think it has prepared me quite well". In post workshop comments many students reported that the pre-assessment skills building workshop was beneficial prior to starting group work as student verbatim's illustrate: "good tips on how to work together"; "I feel it was very practical however others in my group continued to ignore it. I felt it was maybe a little too idealistic". Although, some students considered it not particularly helpful: "didn't really"; and others felt that it helped with students' expectations: "was clearly written what was expected" and "It helped to engage with students and allocate tasks".

\section{Thematic analysis of open-ended questions:}

The main themes that emerged from the thematic analysis of open-ended survey questions are presented in Table 5.

Table 5: Main themes from thematic analysis of pre and post- group work workshop feedback.

\begin{tabular}{|l|l|l|}
\hline & $\begin{array}{l}\text { Pre- Group } \\
\text { work }\end{array}$ & $\begin{array}{l}\text { Post- Group } \\
\text { work }\end{array}$ \\
\hline Main Themes: & & \\
\hline Pre-assessment skills building workshop beneficial & $44 \%$ & $28 \%$ \\
\hline Pre-assessment skills building workshop not beneficial & $7 \%$ & $8 \%$ \\
\hline Benefitted from collaborating and learning from others & $60 \%$ & $31 \%$ \\
\hline Concerns or issues with personality conflicts & $64 \%$ & $31 \%$ \\
\hline Social benefits (meeting new people) & $30 \%$ & $27 \%$ \\
\hline Time management (others and self) & $31 \%$ & $55 \%$ \\
\hline Equal contribution by all team members & $24 \%$ & $33 \%$ \\
\hline Developing confidence/interpersonal skills in group work & $19 \%$ & $32 \%$ \\
\hline Lack of confidence/anxiety over group tasks & $6 \%$ & $2 \%$ \\
\hline Pre-assessment skills building workshop enhance my learning and & $49 \%$ & \\
\hline confidence going into group work & & \\
\hline Personality and conflicts or communication breakdown & & $32 \%$ \\
\hline All team members worked well together & & $12 \%$ \\
\hline
\end{tabular}


Prior to commencing group work but after attending the pre-assessment skills building workshop, students were asked what they thought 'the best' and 'more difficult' aspects of group work would be.

Students stated that they felt that the best aspects of group work would be collaborating and learning from others whilst getting to know people within the course. Below is a selection of the student responses received: "having many different brains come together to complete the assessment"; "if all goes well the teamwork aspect will be nice"; and "To find strengthens and weaknesses of each member and achieve a good mark in all areas".

When students were asked what they thought the 'more difficult' aspects of group work would be, many comments related to concerns that group work could be socially challenging: "the initial meeting, getting to know people. Not be so passive"; "different personalities possibly clashing"; and; "if others don't pull their weight". Concerns were also raised about how to manage other students' expectations and personalities: "where I live - distance to attend meetings and work/kids etcexpectations of other people"; "learning to appreciate everyone in the group is different, We will all think differently" and; "organising a group of people from varying demographics, although I think it is a valuable learning tool".

Overall, when students were asked how the pre-assessment skills building workshop developed their confidence to participate in group work, the consensus was mixed, as illustrated by the following: "didn't really increase my confidence, but it made me psychologically ready to take the group work lead".; and "I'm still quite nervous, but feel more confident than I did when I was heading into class tonight". Many students found attending the pre-assessment skills building workshop provided all group members with a baseline understanding of how to get the most out of working in a group prior to starting, or meeting other group members e.g. before "encouraged me to not be so scared about working in a group"; and "I feel everyone is on an even playing field. Makes everyone involved more confident". Other students didn't think it was helpful at all and said students need to meet and negotiate as required: "didn't, still uncertain" and "it has not really. But once in your group you settle in".

One of the strongest themes to emerge was that students felt that their attendance at the preassessment skills building workshop helped them to be better aware of conflicts that may arise in group work and gave them strategies to help manage them. Comments included: "just remember the task and don't take things personal"; "understanding that it's not going to be $100 \%$ smooth and there will be small confrontations, but that is normal", "and it's beneficial, even though you may already be aware-just to reinstate that conflicts may occur". Students also stated that the pre-assessment skills building workshop informed them of the additional support options available if there were conflicts that couldn't be resolved. As the comments illustrate: "there are support networks in place to help deal with the problems that may arise" and "know who to go to".

After the conclusion of the group work assignment students were again asked their thoughts on the benefit of the pre-assessment skills building workshop and if the information presented helped to prepare them for working in a group. Many indicated that there were significant benefits, such as early social connections, how to work with differing personalities and provision of consistent messaging of expectations in relation to allocation of tasks, as the below selection of comments illustrates "was clearly written what was expected"; "It helped to engage with students and allocate tasks" and "prepared me to deal with the varied personalities within the group". There were some students who responded that the pre-assessment skills building workshop "didn't really" help.

Upon conclusion of the group work, students were also asked about what they thought were the best aspects of group work. Many stated that they considered it to be meeting people within the first few weeks and that it provided an avenue for early introductions and building of social connections, whilst others said that it helped them to learn new content and develop study groups for the rest of their 
course. The following selection of students' comments illustrate the ways the group work was helpful: "making new friends at the start of the course"; "Good to get know everyone in the beginning of the year"; "group learning has helped me to learn the content"; "study partners".

The overall consensus highlighted that the most difficult aspects of the group work task were related to time management, shared workload and commitment to group assignment and the lack of organisation and communication skills as illustrated in the comments: "getting together to meet with everyone's busy schedules"; "Our group reduced significantly so the workload doubled for all of us, Also meetings were hard to organise due to time restraints"; "Not equal contribution"; "too many in the group that weren't really interested". Some students had little to no difficulties working with their group stating that they: "didn't have any difficulties, had an awesome group".

\section{What the students have to say about SPARK?}

Sixty percent of students surveyed thought SPARK was beneficial (Table 6) because it allowed them to analyse their own and other contributions to the group work, enhanced their reflective skills and provided a fair assessment of all group members' contributions. As illustrated in the selected comments students felt that SPARK enabled them to: "to express concerns of group members"; and highlighted the impact on motivation to participate with comments like: "you wanted to do a good job, so your group got good marks as well", and "Able to express my thoughts". Some students indicated they would have preferred their comments to have been anonymous and others considered that students didn't care about the marking criteria of SPARK so it was of no benefit.

Table 6. Survey results and thematic analysis of benefits of using SPARK.

\begin{tabular}{|l|l|}
\hline & Post Group work \\
\hline Enhance my learning and/or develop reflective practise & $15 \%$ \\
\hline Provides fair contribution mark to group members & $15 \%$ \\
\hline Enabled analysis of all participants individual and group contribution & $13 \%$ \\
\hline SPARK beneficial & $60 \%$ \\
\hline SPARK not beneficial & $25 \%$ \\
\hline
\end{tabular}

\section{Discussion:}

Effective teaching strategies are necessary to help mature aged students in their transition to study in a university environment. For many mature-aged students returning to education an identity shift is needed to facilitate a student identity to develop and to allow them to become engaged with academic learning. Although keen to re-engage with education, many mature aged students feel a sense of uncertainty and lack confidence about their capability to study (James, 2013; Relf et al., 2017) in part due to disadvantaged educational backgrounds and/or negative previous educational experiences (Klinger \& Murray, 2011).

Our previous research (McCall \& Relf, 2015) piloted a novel teaching approach to support mature aged students' transition into the student role by forming connections within their peer group and creating a sense of connection in the first few weeks of being enrolled in their enabling program. The importance of establishing social connectedness has been identified as an important factor in engaging mature aged students within their enabling program (Seary \& James, 2016). Anecdotal feedback from enabling students now enrolled in their undergraduate degree indicated that the social connection formed within the first few weeks of their enabling program had persisted during their undergraduate studies providing a valuable support network. This project aimed to assess the effectiveness of this teaching strategy to enhance academic engagement and success for student cohorts enrolled in the 'Science for Nursing and Midwifery' courses in 2016. 


\section{Overview of a 2-year study into tertiary preparation student's perception of integrating group work skills and assessment.}

The experiences of students in group work in this study were similar to those reported in the pilot study evaluation (McCall \& Relf, 2015).

For all students, the most positively rated responses and comments were around the social benefits arising from participating in group work early on in their first semester of their enabling program at the University of Newcastle. In particular, most students felt that the pre-assessment skills building workshop was beneficial because it gave them the skills to deal with conflicts that may arise during group work. This was because the workshop focussed on explicitly scaffolding positive group work behaviours and expectations for students and linking these positive group work behaviours with their final assessment mark for the group work assignment.

Group work is not without it challenges within enabling programs. Many students enrol in an enabling program to assess whether university study is for them (Relf et al., 2017), with a number of students deciding that university study is not for them before leaving and pursuing other educational opportunities or withdrawing for personal circumstances (Hodges et al., 2013). A number of students expressed their frustration that members of their group did not participate or dropped out during the course of the group work assignment. These issues are similar to those reported by Seary and James (2016) who found the same themes in students enrolled in an enabling program at their institution. Older students appeared to be more confronted with working in groups than younger students, an issue also highlighted by Willans (2019). However, although some students reported that they did not enjoy aspects of the group work, they persisted and completed the group work assignment.

Students responded and commented favourably that the use of SPARK (Self and Peer Assessment Toolkit; Wiley 2014) was beneficial because it allowed them to develop their skills in reflection and also provided a vehicle to assess the contributions made by all students within their group. The SPARK assessment criteria scaffolded positive group behaviours for students during completion of their group work. The students who contributed to group work felt SPARK allowed their efforts and contributions to the group to be recognised and rewarded whilst those students who contributed less, or not all, were not. This theme was strongly present in both cohorts. With the time pressures faced by students in the enabling program, due to other commitments outside of their university studies, many students appeared concerned that the group members who did not contribute their fair share to the assessment task would receive the same marks for much less effort. Students who did engage with their group commented that one of the aspects they were most concerned about was finding the time to meet up as a group because of their outside commitments. These time concerns have been reported by other researchers of enabling programs (Bennett \& Burke, 2017; Willans, 2019).

\section{Strategies to support mature aged students returning to study to make the transition into nursing/midwifery undergraduate degrees.}

This teaching strategy for group work was designed to be multi-layered, addressing curricula and cocurricula needs for mature aged students returning to study. It was considered important for students to have a positive experience in their first assessment, to help to shape their student identities (Debenham \& May, 2005). Anecdotally it is considered that students enrolled in enabling programs have a lack of confidence in their ability to undertake their initial assessments. To reduce this sense of anxiety, we surmised that a group work assignment could reduce their anxiety by allowing students to use some of their life skills with the group work experience. We also recognised that nurses are required to work in interdisciplinary teams within hospitals. Therefore, developing the ability to work in groups from the start of a student's academic engagement at university is important. However, we recognised that working in a group is problematic without the correct support and that students in undergraduate studies find that group work induces anxiety. It was hoped that the dual teaching strategies would help students gain a positive experience in their first assessment task. 
The findings show that while many of the students found aspects of group work difficult, they felt less positive about how group work had engaged them. However, many of the students were still persisting in the course when the second survey was taken around week 9 of a 12 week semester. Some of the analysis does support, how for some students, the ability to connect with other students early in their program helped them to feel more connected to their studies and hence their student identity. Many of the comments made by the students indicate that the frustrations around group work had to do with making commitments to the meetings, differences in group members' abilities to manage time and to be organised to meet group work expectations. These can impact on the collective outcome achieved by the group and the student's ability and willingness to remain connected.

We propose that introducing group work at such an early stage for students enrolled in an enabling program allows them to form social connections that encourage persistence in their studies and to establish an identity as a university student. By providing a scaffolded experience where positive group work behaviours are embedded into the assessment criteria, students are actively encouraged to engage with each other and achieve success in their first assessment. That is, for this assessment the process and product were as important as each other. For students who may be anxious about their first assessment, support provided by peers and the ability to choose a task suited to them within the group work allowed not only use of skills formed during prior life experiences but also encouraged peer support, enabling a successful outcome for most group members in relation to the first assignment. Peer learning is acknowledged as the most effective way for students to learn and to retain new knowledge and skills while building upon current evidence-based approaches designed to develop group work skills within nursing programs (Carlson et al., 2019).

In their professional lives, nurses must work in teams and negotiate with people. Group work during their undergraduate studies allows nurses to develop skills in working with diverse people and groups, managing conflict, and negotiating (Lee, Ahonen, Navarette \& Frisch, 2015). Introducing group work to enable students aspiring to undertake an undergraduate nursing degree also introduces students to learning approaches that will be used in their undergraduate degree. It was hoped that by providing students with resources and evaluation tools they would develop group work and self-reflection skills that would support their success in their future studies and profession.

\section{Conclusion}

This follow-up study confirms the findings from our pilot study conducted in 2015 . We propose that introducing group work at such an early stage within enabling programs allows students to form social connections that encourage persistence in their studies. The findings from this study suggest that even though students may face difficulties in some aspects of their group work overall it was a positive experience because the pre-assessment skills building workshop provided them with the tools to deal with conflict arising in group work. Introducing group work early in an academic career, particularly for mature aged students returning to study, can help these students transition to university study and establish their study identity, which will facilitate persistence with their studies. 


\section{References}

Braun, V., \& Clarke, V. (2014). What can "thematic analysis" offer health and wellbeing researchers? International Journal of Qualitative Studies on Health and Well-being, 9.

Bennett, A., \& Burke, P. (2017). Re/conceptualising time and temporality: an exploration of time in higher education. Discourse: Studies in the Cultural Politics of Education, 39(6), 913-925. doi:10.1080/01596306.2017.1312285

Carlson, E., Stenberg, M., Lai, T., Reisenhofer, S., Chan, B., Cruz, E., Leung, D., Wong, A., \& Chan, E.A.(2019). Nursing students' perceptions of peer learning through cross-cultural student-led webinars: A qualitative study. Journal of Advanced Nursing, 75, 1518-1526. http://dx.doi.org/10.1111/jan.13983

Davies, W. M. (2009). Groupwork as a form of assessment: Common problems and recommended solutions. Higher Education, 58(4), 563-584. doi: http://dx.doi.org/10.1007/s10734-009-9216-y

Dawson, J. (2007). Using personal capital to find your own path to successful university study. In J. Scevak, \& R. Cantwell (Eds.), Stepping stones: A guide for mature-aged students at university (pp.47-56). Camberwell, Vic.: ACER Press.

Debenham, J., \& May, J. (2005). Making connections: A dialogue about learning and teaching in a tertiary enabling program. Australian Journal of Adult Learning, 45(1), 82 - 105. Retrieved from https://search-proquestcom.ezproxy.newcastle.edu.au/docview/89069123/fulltextPDF/455D1766C46F4F85PQ/5?accountid=10499

Devlin, M., Kift, S., Nelson, K., Smith, L., \& McKay, J. (2012). Effective teaching and support of students from low socioeconomic status backgrounds: Practical advice for teaching staff. Retrieved from http://www.lowses.edu.au/assets/Practical\%20Advice\%20for\%20Teaching\%20Staff.pdf

Hodges, B., Bedford, T., Hartley, J., Klinger, N., Murray, N., O’Rourke, J., \& Schofield, N. (2013). Enabling retention: Processes and strategies for improving student retention in university-based enabling programs. Retrieved from http://www.enablingeducators.org/resources/CG10_1697_Hodges_Report_2013.pdf

Jackson, D., Hickman, L. D., Power, T., Disler, R., Potgieter, I., Deek H., \& Davidson, P. M., (2014). Small group learning: Graduate health students' views of challenges and benefits. Contemporary Nurse, 48 (1), 11-128.

Kift, S., Nelson, K., \& Clarke, J. (2010). Transition pedagogy: A third generation approach to FYE - A case study of policy and practice for the higher education sector. The International Journal of the First Year in Higher Education, 1(1), 1-20.

Klinger, C.M. \& Murray, N. (2011). Transitioning from enabling education into higher education: A case study of the benefits and challenges presented to and by mature students with life experience. Journal of the Educational Research Group of Adelaide (ERGA), 2(2), pp.19 - 26.

Lee, C.J., Ahonen, K., Navarette, E., \& Frisch, K. (2015). Successful student group projects: Perspectives and strategies. Teaching and Learning in Nursing, 10(4), 186-191.

McCall, D. \& Relf, B. (2015). A GPS for Group work: Providing the best route to a successful group work experience for enabling students. Proceedings of the 2015 STARS Conference, Melbourne, Victoria. Retrieved from: http://www.unistars.org/papers/STARS2015/03F.pdf

Relf, B., Crawford, N., O’Rourke, J., Sharp, S., Hodges, B., Shah, M., \& Katersky Barnes, R. (2017). Lighting the path(way): Articulating curriculum design principles for open access enabling programs. Retrieved from: https://ltr.edu.au/resources/SD15-5063_NEWC_Relf_Final\%20Report_2017.pdf

Seary, K. \& James, T. (2016). 'Show up': Is that the recipe for success? Proceedings of the Foundation and Bridging Educators of New Zealand Conference 2016. Retrieved from http://fabenz.org.nz/wpcontent/uploads/2016/12/Karen-Seary-and-Trixie-James.pdf

Smith, M., \& Rogers, J. (2014). Understanding nursing students' perspectives on the grading of group work assessments. Nurse Education In Practice, 14(2), 112-116. doi:10.1016/j.nepr.2013.07.012

Thomas, L. (2012). What works? Facilitating an effective transition into higher education. Widening Participation and Lifelong Learning, 14, 4-24.

Whannell, R., \& Whannell, P. (2015). Identity theory as a theoretical framework to understand attritions for university students in transition. Student Success, 6(2), 43 - 52.DOI: https://doi.org/10.5204/ssj.v6i2.286 Retrieved from https://studentsuccessjournal.org/article/view/572

Willians, J. (2019). Tales from the borderland: Enabling students' experiences of preparation for higher education. International Journal Studies in Widening Participation. 6(1), 48-64. 
Willey, K. (2014). Improving learning and developing professional judgement in large classes through collaboration and self and peer assessment. Retrieved from Office for Teaching and Learning website http://www.olt.gov.au/resource-improving-learning-developing-professional-judgement-through-collaborativeself-peer-assessment

The authors may be contacted via

deanna.mccall@newcastle.edu.au

Please cite this paper as:

McCall, D. \& Relf, B. (2020). Supporting mature aged students develop group work skills: A review of a two-yearstudy of students' experience of group work within their pre-nursing program. Journal of the Australian and New Zealand Student Services Association, 28(2), 67-79. doi.org.10.30688/janzssa.2020.06 


\section{Appendix 1}

Pre - Group work survey administered at during the pre-assessment skills workshop

Prior to commencing your group work, please complete the following questions.

1. Please tick your age range:

\begin{tabular}{|l|l|l|l|l|l|}
\hline $\begin{array}{l}20 \mathrm{yrs} \& \\
\text { under }\end{array}$ & $21-25 \mathrm{yrs}$ & $26-30 \mathrm{yrs}$ & $31-40 \mathrm{yrs}$ & $41-50 \mathrm{yrs}$ & $51 \mathrm{yrs} \&$ over \\
\hline & & & & & \\
\hline
\end{tabular}

Please circle your response on the following scales with $1=$ strongly disagree, $2=$ disagree, $3=$ uncertain, $4=$ agree and $5=$ strongly agree.

2. Prior to commencing group work, I think it will be:

\begin{tabular}{|l|l|c|c|c|c|c|}
\cline { 3 - 6 } \multicolumn{2}{l|}{} & $\begin{array}{l}\text { Strongly } \\
\text { disagree }\end{array}$ & Disagree & Uncertain & Agree & $\begin{array}{l}\text { Strongly } \\
\text { agree }\end{array}$ \\
\hline 1. & Socially beneficial to me & 1 & 2 & 3 & 4 & 5 \\
\hline 2. & Helpful to my learning & 1 & 2 & 3 & 4 & 5 \\
\hline 3. & Improve my self-confidence & 1 & 2 & 3 & 4 & 5 \\
\hline 4. & $\begin{array}{l}\text { Improve my understanding of } \\
\text { the course material }\end{array}$ & 1 & 2 & 3 & 4 & 5 \\
\hline 5. & Engage me in learning & 1 & 2 & 3 & 4 & 5 \\
\hline 6. & $\begin{array}{l}\text { Help me gain problem solving } \\
\text { skills }\end{array}$ & 1 & 2 & 3 & 4 & 5 \\
\hline 7. & Enable me to think critically & 1 & 2 & 3 & 4 & 5 \\
\hline 8. & $\begin{array}{l}\text { Enhance my communication } \\
\text { skills }\end{array}$ & 1 & 2 & 3 & 4 & 5 \\
\hline 9. & Enhance my teamwork skills & 1 & 2 & 3 & 4 & 5 \\
\hline 10. & Enable me to learn from others & 1 & 2 & 3 & 4 & 5 \\
\hline
\end{tabular}

3. How do you think the pre-assessment skills building workshop has prepared you for group work?

4. From the information presented in the pre-assessment skills building workshop:

a. What do you think will be the best aspects of group work?

b. What do you think will be the more difficult aspects of group work?

5. How did the pre-assessment skills building workshop increase:

a. your confidence about participation in group work, and

b. your awareness of dealing with conflicts that may arise? 


\section{Appendix 2.}

\section{Post - Group work survey administered in class}

Now you have finished your group work, please comment on the following questions:

1. Please tick your age range:

\begin{tabular}{|l|l|l|l|l|l|}
\hline 20 yrs $\&$ under & $21-25$ yrs & $26-30$ yrs & $31-40$ yrs & $41-50$ yrs & 51 yrs \& over \\
\hline & & & & & \\
\hline
\end{tabular}

Please circle your response on the following scales where:

$1=$ strongly disagree, $2=$ disagree, $3=$ uncertain, $4=$ agree and $5=$ strongly agree .

2. After completing the group work in this course, I think group work was:

\begin{tabular}{|l|l|l|l|l|l|l|}
\cline { 3 - 7 } \multicolumn{2}{l|}{} & $\begin{array}{l}\text { Strongly } \\
\text { disagree }\end{array}$ & Disagree & Uncertain & Agree & $\begin{array}{l}\text { Strongly } \\
\text { agree }\end{array}$ \\
\hline 1. & Socially beneficial & 1 & 2 & 3 & 4 & 5 \\
\hline 2. & Helpful to my learning & 1 & 2 & 3 & 4 & 5 \\
\hline 3. & Improved my self-confidence & 1 & 2 & 3 & 4 & 5 \\
\hline 4. & $\begin{array}{l}\text { Improved my understanding of } \\
\text { the course material }\end{array}$ & 1 & 2 & 3 & 4 & 5 \\
\hline 5. & Engaged me in learning & 1 & 2 & 3 & 4 & 5 \\
\hline 6. & $\begin{array}{l}\text { Helped me gain problem } \\
\text { solving skills }\end{array}$ & 1 & 2 & 3 & 4 & 5 \\
\hline 7. & Enabled me to think critically & 1 & 2 & 3 & 4 & 5 \\
\hline 8. & $\begin{array}{l}\text { Enhanced my communication } \\
\text { skills }\end{array}$ & 1 & 2 & 3 & 4 & 5 \\
\hline 9. & Enhanced my teamwork skills & 1 & 2 & 3 & 4 & 5 \\
\hline 10. & $\begin{array}{l}\text { Enabled me to learn from } \\
\text { others }\end{array}$ & 1 & 2 & 3 & 4 & 5 \\
\hline
\end{tabular}

3. How did the information presented in the pre-assessment skills building workshop prepare you for working in a group?

4. What do you think were the best aspects of group work?

5. What do you think were the more difficult aspects of group work?

6. Do you think using SPARK was beneficial? YES / NO (please circle one)

a. Please explain your answer. 